\section{Intimate partner violence, female employment, and male backlash in Rwanda}

\section{Kade Finnoff}

"Most survivors describe the genocide as a bloodbath during which rape was inevitable for practically all females - implying that, whether or not they have chosen to describe what happened to them, nearly all the women and adolescent girls who survived the genocide are now living with the traumatizing memory of a brutal sexual attack that they had suffered or witnessed firsthand."

—Donovan (2002)

"Civil conflicts ... have specific forms of violence, including state terror enacted by agents or by vigilante groups or paramilitaries with state complicity directed primarily against innocent civilians; much of this violence is again gender specific, with women being targeted in specific ways through gender-based humiliation and torture. Moreover, many feminist scholars have argued that sexual violence against women specifically is a constitutive aspect of war. While it is clear that war is gendered, what is less recognized is that the post-war period is equally gendered. What happens to women victims of war violence? What role does righting gender inequities play in post-war reconstruction?"

$\mathrm{M}$ ethodologically comparable empirical research in developing countries on the prevalence, incidence, and determinants of intimate partner violence is sparse. Moreover, much of the work is concentrated on understanding its public health ramifications. The most comprehensive such study is the World Health Organization's Multi-Country Study on Women's Health and Domestic Violence against Women. Collecting data from over 24,000 women in 10 countries, it supported diverse prior studies in which a higher prevalence of intimate partner violence was found among women who have lower levels of education, greater financial dependence, a family history of violence, lack of wider social support networks, have a partner who abuses alcohol, have an unemployed partner, or live in a context that endorses or accepts violence against women. ${ }^{1}$ Beyond this general dearth of knowledge, gender violence in civil war is particularly ill-understood, and still greater gaps in our understanding exist in regard to possible long-term patterns of gendered power and violence in countries affected by war.

Civil war fractures society and previously established norms. Gender norms in particular are altered when men are either absent or unable to fulfill their previous roles of primary wage earners. Following civil war, in low-income countries, women often enter the paid labor force due to necessity (large numbers of female-headed households) and greater employment opportunities (through the influx of targeted international aid and NGOs). From standard bargaining models, this should have the effect of empowering women and therefore reducing their vulnerability to violence from intimate partners. However, relative female economic empowerment often occurs at the same time that men are experiencing high unemployment and frustration. To the extent that these phenomena change the dynamics of gender relations, especially in an environment of psychological and emotional distress, there may be a propensity to an eruption of conflict within the household. In some cases this conflict is expressed nonviolently, but in others it can be accompanied by acts of physical and sexual violence, especially when the social mores of society remain unchanged in other ways. ${ }^{2}$ In this sense, overt violence against women during conflict can be said, postwar, to "retreat" into the domestic sphere.

The implied hypotheses have not been expressly tested using standard economic methodology. This article seeks to address these issues by examining the correlates of intimate partner violence in post-genocide Rwanda using data from a widely used and standard survey, the Demographic and Health Survey (DHS). Rwanda is a particularly apt case study as large-scale physical and sexual violence occurred during the genocide, with estimates ranging from 250,000 to 500,000 women raped. ${ }^{3}$

Using data from the 2005 DHS, in which women were surveyed alone and which included questions on intimate partner violence, the article explores three separate but linked issues. First, it seeks to identify the most common correlates of intimate partner violence. The DHS survey allows for the separate examination of three categories of intimate partner violence: physical, emotional, and sexual. Unlike similar studies done in different contexts, ${ }^{4}$ results are disaggregated by the kind of violence experienced Because these three kinds of violence are different both in conception and as forms of male domination, it is important to see whether there are differences in their patterns and prevalence. Distinct patterns by subcategory are found.

Second, the article examines possible links between women's and men's labor market engagement and the propensity for different forms of violence. As already suggested, patterns of labor market involvement and their effect on gender relations are complex and potentially nonlinear. Controlling for other risk factors, the main finding here is that of a positive and significant female wage effect on the probability of being the target of sexual (but not physical or emotional) violence when the male is disempowerment, defined as a situation where the woman works and receives payment while her spouse lacks paid employment. Where men are disempowered in 
this sense, women are twice as likely to be the victims of sexual assault compared to women who are not in such a relationship. This finding suggests that sexual violence in particular may constitute a different and more complex form of male domination. Running counter to canonical bargaining models in economics that predict that greater female economic empowerment leads to their greater bargaining power and hence to lower levels of (undifferentiated) violence against them, the finding instead supports sociological theories of male disempowerment, or "male backlash." The character of intra-household bargaining may need to be reconceptualized. ${ }^{5}$

Third, the article explores the long-term correlation between exposure to genocide and postwar intimate partner violence and finds that variation in genocide death rates are positively and statistically significantly correlated with reported sexual and emotional violence in 2005. ${ }^{6}$ Moreover, it can be shown that more violence-prone provinces during war are also the ones in which women experience higher rates of violence afterwards.

\section{Gender-based violence during the genocide and legal changes since then}

In the period leading up to the 1994 genocide, anti-Tutsi propaganda in the media was explicitly gendered, promoting the notion of extreme sexual promiscuity in Tutsi women. As such they were portrayed as threats to Rwandan (and in particular Hutu) society. Four of the highly publicized "Hutu 10 commandments" explicitly addressed gender relations (Green, 2002):

- Every Hutu should know that a Tutsi woman, wherever she is, works for the interest of her Tutsi ethnic group. As a result, we shall consider a traitor any Hutu who: marries a Tutsi woman; befriends a Tutsi woman; employs a Tutsi woman as a secretary or a concubine.

- Every Hutu should know that our Hutu daughters are more suitable and conscientious in their role as woman, wife, and mother of the family. Are they not beautiful, good secretaries and more honest?

- Hutu woman, be vigilant and try to bring your husbands, brothers and sons back to reason.

- The Rwandese Armed Forces should be exclusively Hutu. The experience of the October [1990] war has taught us a lesson. No member of the military shall marry a Tutsi.

Moderate Hutu women were also the targets of the propaganda. For example, prior to the genocide, then-deputy prime minister, Agathe Uwiringiyimana was portrayed as sexually promiscuous and a threat to the nation. ${ }^{7}$ She was murdered within hours of assuming the post of prime minister after the plane crash that killed President Habyarimana and triggered the beginning of the genocide.

Women experienced high levels of sexual violence during the genocide. As mentioned, estimates range from a lower bound of 250,000 to an upper bound of 500,000 women raped, and the end of the genocide did not bring with it the end of sexual violence against women. There are numerous cases of young women captured and detained in sexual slavery both during and after the genocide. A term was even coined for women found in hiding by militias - ceiling brides or women of the ceiling. Seen as war booty, these women were held against their will and routinely raped. ${ }^{8}$

Since 1994, there have been many legal changes to enhance gender equity and to increase the political and institutional participation of women in Rwandan society. Rwanda now boasts the largest political representation of women in the world, with 56 percent of the Rwandan parliament female. A host of legal changes have been made and incorporated into the constitution ratified in 2003, whereby women are now legally recognized as equal to men. Laws have also changed to give women some limited rights to household assets in the case of the death of a husband. ${ }^{9}$

On 15 July 2008, the Rwandan Senate passed the first law specifically on the prevention and punishment of gender-based violence. Prior to this, gender-based violence, including sexual violence, was punishable under Article 30 of the 1977 Rwandan Penal Code. However, there were substantial limitations in the Code, for example the lack of a definition of rape. ${ }^{10}$ The 2008 law addressed many of the previous gaps, including definitions of gender-based violence and rape. While intended to provide a clear legal mandate for prosecuting crimes, surprising inequities in punishment guidelines remain. For example, apart from the identity of the perpetrator, rape and conjugal rape have the same definition, yet punishment for rape is imprisonment for 10 to 15 years while for conjugal rape it is 6 months to 2 years. Punishment for adultery now carries a longer imprisonment term than conjugal rape

Despite the new law, spousal abuse remains common in contemporary Rwandan society. A 2004 joint study on gendered violence by the Ministry of Gender and Family Promotion and the International Rescue Committee found 53.8 percent of women reporting domestic violence by their partners within the twelve months preceding the survey. ${ }^{11}$ Intimate partner violence takes place in the context of widespread gender inequities. Women who leave abusive relations have often been subjected to harsh gender penalties, ranging from lack of legal rights in ownership or user rights of household assets such as land to losing parental rights such as custody of children. ${ }^{12}$

\section{Postwar prevalence and correlates of intimate partner violence in Rwanda}

A major drawback of empirical work on intimate partner violence is that different forms of violence are aggregated into a single measure. Thus, it is not known whether different forms of violence have the same risk factors associated with them. For example, in the case of the aforementioned 2005 WHO study, even though the data were collected in disaggregated form, results given were an aggregation of physical and sexual violence. ${ }^{13}$ While there was some recorded overlap between physical and 
sexual violence, in three out of 12 countries covered a substantial number of women had experienced only sexual violence. In a postwar setting-following widespread gendered violence during war-it is especially important to examine each type of violence separately.

Data collected in the Rwandan Demographic and Health Survey in 2005 (RDHS-III) included a module on domestic violence, which was applied to half of the households interviewed and included 4,066 randomly chosen women. Because of its sensitive nature, a female interviewer administered the domestic violence questionnaire in private without any other family members present or even in close proximity. ${ }^{14}$ Due to the extremely personal and sometimes deeply traumatic nature of these experiences, it is unrealistic to expect a large survey to capture the full extent of intimate partner violence. Hence the data presented in this article are likely to be underestimates of the true level of sexual violence by intimate partners.

Using an abbreviated version of the Conflict Tactics Scale, the questionnaire covered three broad types of violence: physical, sexual, and emotional. Detailed information was collected on spousal violence for ever-married or cohabiting women, including divorced, separated, or widowed women. Of the 4,066 respondents, 1,341 were currently married, 995 were cohabiting, 157 were widowed, and 39 were divorced. Respondents were asked whether they had experienced a range of specific acts that covered a spectrum from less to more severe forms of emotional, physical, and sexual violence. ${ }^{15}$ The questionnaire gathered data to assess both the prevalence of intimate partner violence over the women's adult life and within the year prior to the interview. The survey included socioeconomic background questions asked of each respondent. While data on consumption or income measures were not collected, information on household assets and characteristics is available. Socioeconomic background information on the woman's current spouse was also collected, including age, education, and employment.

Overall 38.6 percent of ever-married or cohabiting women reported having experienced physical, emotional, or sexual violence by their intimate partner at some time since age 15 . Table 1 presents the prevalence of intimate partner violence by residence (urban/rural) and type of violence. Physical violence is the most common type reported by ever-married women (35.6 percent), followed by sexual violence (13.9 percent) and emotional violence (13 percent). The same pattern is observed among currently married women, but at slightly lower levels in each category. These results are consistent with data from other empirical studies. ${ }^{16}$

Ever-married women residing in urban areas report somewhat lower overall levels of intimate partner violence (36.9 percent versus 38.8 percent for rural women). Disaggregating among types of violence, physical violence for urban residing women is lower (31.5 percent versus 35 percent for rural women), but levels of emotional and sexual violence are substantially higher. In particular, urban women report much higher levels of sexual violence (22 percent) compared to their rural counterparts (12.7 percent).
Table 1: Prevalence of intimate partner violence by category of violent act for ever-married or cohabiting women (percentages)

$\begin{array}{lrrr}\text { Type of violence } & \text { Rural } & \text { Urban } & \text { Total } \\ \text { (Number of observations) } & (1591) & (294) & (1885) \\ & & & \\ \text { Intimate partner violence } & 37.6 & 32.9 & 37.1 \\ \text { - Emotional } & 9.5 & 11.7 & 9.7 \\ \text { - Physical } & 33.7 & 27.5 & 33.0 \\ \text { - Sexual } & 11.7 & 17.8 & 12.4 \\ \text { Emotional } & & & \\ \text { - Humiliated her in front of others } & 8.8 & 10.8 & 9.0 \\ \text { - Threatened her or someone close to her with harm } & 3.4 & 4.9 & 3.6 \\ \text { Physical } & & & \\ \text { - Pushed/shaken/thrown something at her } & 15.1 & 12.5 & 14.8 \\ \text { - Slapped or arm twisted } & 26.5 & 19.4 & 25.7 \\ \text { - Punched with fist or something harmful } & 12.3 & 10.9 & 12.2 \\ \text { - Kicked or dragged her } & 6.5 & 6.8 & 6.5 \\ \text { - Tried to strangle or burn her } & 1.4 & 2.7 & 1.5 \\ \text { - Threatened with knife, gun, or other weapon } & 1.0 & 2.8 & 1.2 \\ \text { - Attacked with knife, gun, or other weapon } & 0.4 & 1.9 & 1.0 \\ \text { Sexual } & & & \\ \text { - Physically forced unwanted sexual intercourse } & 10.5 & 16.6 & 11.2 \\ \text { - Forced to perform other unwanted sexual acts } & 4.9 & 6.5 & 5.1\end{array}$

Source: Author's calculation based on Rwandan Demographic and Health Survey, 2005.

The most frequent domestic violence act reported by ever-married women was that they had been slapped or had an arm twisted (27.8 percent). The attack with the lowest reported frequency was with a knife, gun, or other type of weapon (1 percent). Sexual violence in the form of forced sexual intercourse by their spouse is the fourth most common form of intimate partner violence (12.9 percent). Urban women report much higher levels of spousal rape than rural women (20.6 vs. 11.8 percent).

\section{Violence by selected characteristics}

Table 2 presents the prevalence of violence by type and selected characteristics for currently married or cohabiting women. In terms of household characteristics, a direct association between a woman's age category and a husband's age category and physical violence is seen, but without any apparent relation between age and 
Table 2: Prevalence of violence by type and selected characteristics of currently married or cohabiting women (percentages)

\begin{tabular}{|c|c|c|c|}
\hline Characteristics & $\begin{array}{l}\text { Emotional } \\
\text { violence }\end{array}$ & $\begin{array}{l}\text { Physical } \\
\text { violence }\end{array}$ & $\begin{array}{l}\text { Sexual } \\
\text { violenc }\end{array}$ \\
\hline \multicolumn{4}{|l|}{ Woman's age } \\
\hline$-17-26$ & 9.6 & 29.4 & 13.5 \\
\hline$-27-36$ & 9.8 & 31.5 & 11.9 \\
\hline$-37+$ & 9.1 & 38.2 & 11.1 \\
\hline \multicolumn{4}{|l|}{ Husband's age } \\
\hline $17-26$ & 8.0 & 26.4 & 11.3 \\
\hline $27-36$ & 9.2 & 26.4 & 13.2 \\
\hline $37+$ & 10.2 & 34.7 & 11.6 \\
\hline \multicolumn{4}{|c|}{ Spousal age difference } \\
\hline - No difference & 9.0 & 25.7 & 11.7 \\
\hline - Wife $>$ Husband & 10.2 & 33.6 & 8.9 \\
\hline - Wife $<$ Husband & 9.5 & 33.6 & 12.6 \\
\hline \multicolumn{4}{|c|}{ Woman's education } \\
\hline - None & 8.3 & 33.5 & 9.3 \\
\hline - Primary & 10.3 & 34.4 & 13.9 \\
\hline - Secondary & 7.8 & 18.5 & 6.5 \\
\hline \multicolumn{4}{|c|}{ Husband's education } \\
\hline - None & 9.8 & 34.7 & 12.8 \\
\hline - Primary & 9.8 & 35.0 & 12.6 \\
\hline - Secondary & 8.0 & 17.6 & 7.6 \\
\hline \multicolumn{4}{|c|}{ Spousal education difference } \\
\hline - No difference & 9.3 & 33.0 & 13.2 \\
\hline - Wife $>$ Husband & 11.9 & 36.3 & 13.6 \\
\hline - Wife $<$ Husband & 8.5 & 30.8 & 8.7 \\
\hline \multicolumn{4}{|c|}{ Number of household members } \\
\hline$-2-4$ & 8.4 & 28.2 & 12.3 \\
\hline$-5-7$ & 11.6 & 37.2 & 13.1 \\
\hline$-8+$ & 6.1 & 31.4 & 8.8 \\
\hline \multicolumn{4}{|c|}{ Number of children } \\
\hline-0 & 3.2 & 15.1 & 10.7 \\
\hline$-1-3$ & 9.6 & 31.0 & 11.9 \\
\hline$-4-8$ & 10.7 & 38.1 & 13.4 \\
\hline$-9+$ & 8.8 & 36.5 & 8.0 \\
\hline
\end{tabular}

Table 2 (continued)

Male children living at home

$-0$

$-1+$

$\begin{array}{lll}8.7 & 27.3 & 11.3\end{array}$

Death of a male child

- No

34.9

- Yes

32.3

Wealth

- Poorest quintile

- Second quintile

$9.4 \quad 34.4$

11.2

- Third quintile

- Fourth quintile

$\begin{array}{rrr}7.3 & 35.4 & 11.9 \\ 11.8 & 37.3 & 12.7\end{array}$

$\begin{array}{lll}1.8 & 37.3 & 12.7\end{array}$

9.2

32.3

12.4

- Fifth quintile

32.3

$\begin{array}{ll}10.2 & 25.7\end{array}$

12.0

Region

- Urban

- Rural

11.5

26.7
33.8

Social support

- Limited family contact

- Limited girlfriend contact

$\begin{array}{lll}28.0 & 50.1 & 26.3\end{array}$

Alcohol abuse

- Does not consume alcohol

- Less severe alcohol abuse

$\begin{array}{lll}7.0 & 22.5 & 10.6\end{array}$

- Severe Alcohol abuse

Female family history of IPV

- No

$\begin{array}{lll}8.3 & 29.0 & 10.0\end{array}$

- Yes

Polygamy

- One wife

9.0

32.1

12.1

- More than one wife

18.4

Genocide intensity

- Low-intensity

- Mid-level intensity

$\begin{array}{rrr}7.6 & 34.2 & 8.6 \\ 10.1 & 30.3 & 14.3 \\ 11.8 & 36.2 & 13.8\end{array}$

Source: Author's calculation based on Rwandan Demographic and Health Survey, 2005. 
emotional or sexual violence. An intriguing pattern emerges in relation to the number of children and intimate partner violence: As the number of children increases up until 8 children, all three forms of violence rise, but from $9+$ children onward, levels of violence decline across the board. There is no clear pattern related to the size of households. ${ }^{17}$ Contrary to expectations, women who have at least one male child living at home reported a much higher incidence of physical violence, but not emotional or sexual violence. There is also a direct association between the probability of physical violence and women who have lost a son.

Regarding social characteristics, women whose husbands limit contact with family and friends experience substantially higher rates of all types of violence, and physical violence in particular. Polygamy is associated with a higher incidence of emotional and physical violence. There is a notable rise in incidence across types of violence for women who report severe alcohol abuse by their husbands. Also notable is the higher violence for women who report witnessing their father beat their mothers. Lastly, a higher intensity of killings during the genocide is associated with higher incidence of emotional and sexual violence across regions.

For labor market characteristics, the most evident pattern is that women who are engaged in wage-employment reported a higher incidence of sexual violence. Women whose husbands are unemployed do not experience notably higher rates of violence across the board, although women whose husbands are employed but unpaid do report higher rates of sexual violence. The employment difference between genders (the "relative employment difference") shows a higher incidence of sexual violence among women who work for wages and whose husbands are unpaid.

\section{Multivariate results}

A logistic analysis is used to investigate the correlates of different types of intimate partner violence by selected characteristics. The dependent variables were defined as emotional, physical, and sexual violence coded as equal to 1 if violence ever experienced and as 0 otherwise. Drawing on a typology of risk factors identified in the literature, the following independent variables were used in the analysis:

- Household characteristics (age, education, household composition, number of children, wealth, region);

- Social characteristics (social support, alcohol abuse, history of violence, polygamy, genocide intensity $)^{18}$; and

- Labor market characteristics (unemployed, working without pay, working for wages, relative employment difference between husband and wife).

Reporting odds ratios, Table 3 (overleaf) presents estimates from the logistic specification of the correlates by type of violence.

\section{Household characteristics}

No discernible patterns across age categories and type of violence are found, and there is little evidence of a consistent relationship between women's education and their experience of violence. Unlike prior studies, women with secondary or higher educations do not appear to experience a protective effect from education. However, there is strong statistical evidence that male secondary education reduces the likelihood of using physical violence (by almost 60 percent).

As to household composition, no systematic pattern linking household size and the prevalence of intimate partner violence across categories is seen. But women in households where there are large numbers of children are more likely to experience emotional, physical, and sexual violence (although the coefficient for sexual violence are not statistically significant). There is an increasing relation between the number of children and the prevalence of emotional and physical violence. Women with more than 9 children are more than eight times as likely to have experienced emotional violence and more than twice as likely to have experienced physical violence as women with no children.

No discernible relation between wealth quintile and type of violence was found. Women in the second and fifth wealth quintiles report statistically significantly higher prevalence rates of emotional abuse, but there is no economic significance readily apparent in this result. Finally, for physical and emotional violence, no systematic variation between rural and urban women is found. But urban women are statistically more likely (in fact, 80 percent more likely) to have experienced sexual violence. This result is at odds with the data collected by the 2005 WHO multi-country study on domestic violence, which found that urban women are much less likely to have experienced sexual violence. ${ }^{19}$

Social characteristics

Strong support is found for the protective role played by women's family and friends in reducing the likelihood of all three types of violence. Women whose husbands limit the women's family contact are over 200 percent more likely to have experienced emotional violence, over 60 percent more likely to have ever experienced physical violence, and over 100 percent more likely to have ever experienced sexual violence. Women whose partners have limited her contact with her female friends are over 100 percent more likely to have experienced emotional or physical violence. For sexual violence this pattern is not observed, indicating an important distinction in the impact of social support by type of violence.

Regarding alcohol abuse, a systematic relation emerges for all forms of violence. Women whose husbands frequently get drunk are more than 500 percent likely to have ever experienced emotional or physical violence and more than 200 percent more likely to have ever experienced sexual violence. This result corroborates 
Table 3: Logistic estimation on prevalence of violence by intimate partner for currently married or cohabiting women (odds ratios)

\begin{tabular}{|c|c|c|c|}
\hline Characteristics & $\begin{array}{l}\text { Emotional } \\
\text { violence }\end{array}$ & $\begin{array}{l}\text { Physical } \\
\text { violence }\end{array}$ & $\begin{array}{l}\text { Sexual } \\
\text { violence }\end{array}$ \\
\hline \multicolumn{4}{|c|}{ Woman's age $(\mathrm{r}=17-26)$} \\
\hline$-27-36$ & 0.763 & 1.044 & 0.808 \\
\hline$-37+$ & 0.55 & 1.385 & 0.813 \\
\hline \multicolumn{4}{|c|}{ Husband's age (r=17-26) } \\
\hline $27-36$ & 1.112 & 1.201 & 1.2 \\
\hline $37+$ & 1.319 & 0.934 & 1.132 \\
\hline \multicolumn{4}{|c|}{ Woman's education ( $\mathrm{r}=$ none $)$} \\
\hline - Primary & 1.17 & 1.23 & $1.583 *$ \\
\hline - Secondary & 1.213 & 0.949 & 0.704 \\
\hline - Higher & - & - & 9.475 \\
\hline \multicolumn{4}{|c|}{ Husband's education (r=none) } \\
\hline - Primary & 0.886 & 1.05 & 0.914 \\
\hline - Secondary & 0.748 & $0.441 * *$ & 0.573 \\
\hline - Higher & - & - & 0.305 \\
\hline \multicolumn{4}{|c|}{ Number of household members $(\mathrm{r}=2-4)$} \\
\hline$-5-7$ & 1.248 & 1.171 & 0.905 \\
\hline$-8+$ & 0.54 & 0.787 & 0.61 \\
\hline \multicolumn{4}{|c|}{ Number of children $(\mathrm{r}=0)$} \\
\hline$-1-3$ & $4.074 *$ & $2.778 * *$ & 1.022 \\
\hline$-4-8$ & $5.115^{*}$ & $3.490 * *$ & 1.414 \\
\hline$-9+$ & $9.182 * *$ & $3.858 * *$ & 1.362 \\
\hline \multicolumn{4}{|c|}{ Male children living at home $(\mathrm{r}=0)$} \\
\hline$-1+$ & 0.924 & 0.974 & 1.193 \\
\hline \multicolumn{4}{|c|}{ Death of a male child $(\mathrm{r}=\mathrm{no})$} \\
\hline - Yes & 0.963 & 0.849 & 0.869 \\
\hline \multicolumn{4}{|c|}{ Wealth ( $\mathrm{r}=$ poorest quintile) } \\
\hline - Second quintile & $2.234 *$ & 1.288 & 1.159 \\
\hline - Third quintile & 1.536 & 0.994 & 1.093 \\
\hline - Fourth quintile & 1.644 & 1.093 & 1.139 \\
\hline - Fifth quintile & $2.082 *$ & 1.056 & 1.089 \\
\hline \multicolumn{4}{|l|}{ Region (r=urban) } \\
\hline - Rural & 0.942 & 0.774 & $1.803 * *$ \\
\hline
\end{tabular}

Table 3 (continued)

Social support 1 ( $\mathrm{r}=$ unlimited family contact)

- Limited family contact 3.085*

Social support 2 ( $\mathrm{r}=\mathrm{unlimited}$ girlfriend contact)

- Limited girlfriend contact 2.165**

Alcohol abuse ( $\mathrm{r}=$ does not consume alcohol)

- Less severe alcohol abuse

$1.725^{*} \quad 2.078^{* *} \quad 1.433$

- Severe Alcohol abuse

$6.248^{* *} \quad 6.165^{* *} \quad 3.054^{* *}$

Female family history of IPV $(\mathrm{r}=\mathrm{no})$

- Yes

$1.499^{*} \quad 1.681^{* *} \quad 1.728^{* *}$

Polygamy (r=husband has one wife)

- More than one wife

$\begin{array}{llll}\text { - Mid-level intensity } & 1.398 & 0.823 & 1.650 *\end{array}$

$\begin{array}{llll}\text { - High-level intensity } & 1.980 * & 1.281 & 1.662 *\end{array}$

Woman's employment ( $r=$ unemployed)

$\begin{array}{llll}\text { - Working without wages } & 1.166 & 1.155 & 1.267\end{array}$

$\begin{array}{llll}\text { - Working for wages } & 0.973 & 1.024 & 1.677^{*}\end{array}$

Husband's employment ( $\mathrm{r}=\mathrm{unemployed})$

$\begin{array}{llll}\text { - Working without wages } & 0.742 & 0.765 & 1.57\end{array}$

$\begin{array}{llll}\text { - Working for wages } & 0.921 & 0.983 & 1.149\end{array}$

$\begin{array}{llll}\text { Number of observations } & 1,868 & 1,869 & 1,867\end{array}$

Notes: * significant at $5 \% ; *$ significant at $1 \% ; \mathrm{r}=$ omitted category;

[-] observations dropped because $n$ is too small.

extensive documentation of alcohol abuse correlated with intimate partner violence. ${ }^{20}$

A strong and consistent pattern is also found between type of violence and whether a woman witnessed her father beating her mother (history of violence). The intergenerational effect is statistically significant across all three types of violence, and strongest for sexual violence: A woman whose father beat her mother is more than 70 percent more likely to have ever experienced sexual violence. This finding is consistent with other research that has found strong intergenerational effects of violence. ${ }^{21}$ In contrast, no consistent relation emerged between polygamy and the various forms of violence. This is contrary to several small studies in central Africa which found a direct association between polygamy and intimate partner violence. ${ }^{22}$

Finally, to test for the effect of levels of sexual violence during the genocide, 
intensity of killings by province is used as a proxy variable. While this does not tell one directly about levels of sexual violence, it is nonetheless likely that there was a close association. For the logistic regression, three binary categorical variables were created: high-level, mid-level, and low-level genocide intensity. A statistically significant correlation is found between prevalence of sexual violence for mid- and high-level intensity of genocidal killings by province (see Table 3 ). Women in provinces with high-intensity genocide-related killings were over 60 percent more likely to have reported sexual violence in $2005 .{ }^{23}$ This relation is not found for physical violence, and is statistically significant for emotional violence only in high-level genocide intensity provinces. While not definitive, these findings lend support to earlier research on sexual violence which finds higher rates in societies with widespread social upheaval and fraying of social and communal ties. ${ }^{24}$

\section{Labor market characteristics}

Economic models of intra-household bargaining predict greater female empowerment from increases in a woman's economic status, such as waged employment. This prediction is tested, examining both female and male employment. Table 4 presents the logistic regression results on violence types and labor market characteristics, controlling for household and community-level effects. Across model specifications, no statistically significant relation is found between emotional or physical violence and employment status. But a strong direct relation is found between female wage employment and the likelihood of having experienced sexual violence. Women who work and receive wages are 68 percent more likely to report having experienced sexual violence by their spouse than those who do not work for wages.

It could be the case that women who work for wages have a higher tendency to report sexual violence (rather than having a higher incidence). To control for this possibility, potential reporting bias is examined for women who work for wages and who report higher levels of all forms of violence. No evidence of a consistent bias is found. ${ }^{25}$ Women's attitude toward violence was also examined and no difference was found between women who work for wages and those who do not.

The direct relation between female wage earning and sexual violence runs counter to extant bargaining models, wherein greater female decisionmaking and access to paid employment increases bargaining power and decreases domestic violence. Perhaps what is being observed here is a contradictory nature of female empowerment: In some respects, access to paid employment may increase female bargaining power, but at the same time it may create tensions within the household as male dominance is threatened.

Sociologists have proposed a theory of "male backlash," wherein men respond with violence as women experience greater economic empowerment relative to men and culturally accepted notions of masculinity are threatened. ${ }^{26}$ For example, in a comparative study of two communities in Kenya and Tanzania, one study found that
Table 4: Logistic estimation on prevalence of violence by type and labor market characteristics (odds ratios)

$$
\begin{array}{lll}
\text { Emotional } & \text { Physical } & \text { Sexual } \\
\text { violence } & \text { violence } & \text { violence }
\end{array}
$$

Variable Models I \& II Models I \& II Models I \& II

Woman's employment ( $r=$ unemployed $)$

$\begin{array}{lllllll}\text { - Working without wages } & 1.091 & 1.166 & 1.056 & 1.155 & 1.391 & 1.267\end{array}$

$\begin{array}{llllll}\text { - Working for wages } & 0.97 & 0.973 & 0.922 & 1.024 & 1.682 * * 1.677 *\end{array}$

Variable Model II only Model II only Model II only

Husband's employment ( $r=$ unemployed)

- Working without wages $\quad 0.742$

- Working for wages 0.921

0.765

0.983

1.57

1.149

Variable Model III only Model III only Model III only

Relative employment difference

- Woman working for wages and husband working without wages

$$
0.594 \quad 0.815 \quad 2.043^{*}
$$

Notes: * significant at 5\%; ** significant at 1\%; model I: ever-married women sample; model II and III: currently married women sample.

economic disempowerment of men relative to women undermined the material foundation of patriarchy and increased the prevalence of sexually aggressive behavior of men. Similarly, examining the prevalence of rape across countries, another study found a high incidence of rape in societies where male power has been destabilized. ${ }^{27}$

To test for relative female empowerment (or relative male disempowerment), a binary variable was created that takes the value of one when women receive wages and their partners are unpaid for their labor, and zero otherwise. ${ }^{28}$ The results, presented in Model III in Table 4, show strong evidence that female economic empowerment relative to men adversely affects levels of sexual violence. When compared to women who do not work for wages, women in wage-employment are over 100 percent more likely to report sexual violence by their unpaid (non-waged) 
spouses. This robust evidence for the "male backlash" effect implies the need to better understand changes in gender identity and social relations within the context of changing economic opportunities and postwar social insecurity. ${ }^{29}$

\section{Conclusion}

Gender violence and sexual torture in civil wars recently have become important areas of research. As part of this set of concerns, it is important to understand the long-term effects on society and the ways in which gendered violence continue to be experienced in countries emerging from civil war. This article investigates the prevalence of intimate partner violence in post-genocide Rwanda. Significant differences are found in the prevalence of different types of gendered violence. Women who live in urban areas, have a primary education (versus no education), and have wage employment experience significantly higher rates of sexual violence. A direct, and increasing, relation between the number of children a woman has and the prevalence of emotional and physical violence is also found.

A second finding is that women who are employed, but whose husbands are not, experience substantially more sexual violence. This finding may be interpreted as "male backlash": Men's reaction to losing power as gender norms are in flux. This finding is contrary to predictions found in the bargaining literature in economics where greater female economic empowerment is posited to result in more favorable outcomes for women. In a postwar society like Rwanda's, models of intra-household bargaining fail to take into account periods of widespread social upheaval where male power has been destabilized. Female economic opportunities, while important in their own right, may not bring about wider social change without addressing masculinity, patriarchal social relations, and the ways in which gender inequities play out within the household. These results also convey the importance of understanding both the long-term effects of various types of state-sanctioned violence and the complex dynamics involved in female economic empowerment during periods of social unrest when male patriarchy is directly challenged.

Finally, the article finds a strong correlation been the prevalence of sexual violence in 2004 and the intensity of violence during the genocide, ten years earlier. This points to the need for further research, to explore the way in which patterns of war-related violence affect gender violence in its aftermath.

\section{Notes}

Kade Finnoff is Assistant Professor of Economics at the University of Massachusetts, Boston, MA, USA. Her email is<kade.finnoff@umb.edu>.

1. WHO: Garcia-Moreno, et al. (2005). Previous studies: In a review of international studies on intimate partner violence, Krahé, Bieneck, and Möller (2005) find only five studies on prevalence rates for domestic violence in developing countries. Much of this work examines socioeconomic differences, gender roles, and cultural acceptance of violence.

2. The experience of violence against women after periods of conflict is a relatively neglected area of research. Notable exceptions include Meintjes et al. (2002), Pillay (2002), and Sideris (2002). Pillay (2002) outlines four elements, not all of which are mutually exclusive, that underlie male violence against women in the aftermath of war. These are the growing power of women, the social acceptance of violence against women, eroding concepts of masculinity, and changes in the economic power of men and women. In Rwanda, post-1994, all of these elements are arguably present

\section{Human Rights Watch (1996b).}

4. See, for example, Panda and Agarwal (2005).

5. A central notion in bargaining theory is that leaving the household is a feasible fallback option for both men and women. Where such options are practically difficult (even if theoretically possible) because of legal difficulties and prevailing norms, a more nuanced understanding of household conflict and cooperation may need to be developed. In particular, one may expect to observe what at first may seem counterintuitive: Women's economic empowerment leading to a greater propensity for conflict as prevailing norms are challenged and men react with sexual violence as a form of control.

6. To be clear: The question on sexual violence in the Rwandan Demographic and Health Survey (DHS) asks whether the respondent had experienced violence over the 12 months prior to the interview (and ever over lifetime). For women reporting sexual violence within the last 12 months prior to the interview, it is therefore possible that the violence experienced occurred in 2004 as well. The data was collected in 2005 and published in 2006 .

7. Powley (2004). 
(C) www.epsjournal.org.uk - Vol. 7, No. 2 (2012)

8. Rape estimates: Based on the standard method of using the number of pregnancies resulting from rape, in turn estimated to range from 2,000 to 5,000; see Human Rights Watch (1996a). Sexual slavery: Human Rights Watch (1996a). Ceiling brides: This term arose because the women were hidden by their captors, or found hiding, in the space between the ceiling and the roof of homes. War booty: Human Rights Watch (1996a); Human Rights Watch (2004).

9. Institutional participation: The Rwandan constitution stipulates that at least 30 percent of decisionmaking positions be filled by women. 56 percent: UNIFEM (2008). Limited rights to household assets: While inheritance laws have been reformed, it is unclear whether this has led to substantial changes in gendered inheritance norms.

10. Failing to define different kinds of acts of gender-based violence has led to widely varying interpretations of the law and to inconsistent verdicts. See Afeefa, et al. (2006); Human Rights Watch (2004).

11. Administered to 722 women in five of the country's eleven provinces, only 477 women were actually interviewed. The survey found that 32.4 percent of women reported verbal or physical abuse by someone other than their spouse or sexual partner over the five years preceding the survey. See Ministry of Gender and Family Promotion (2004).

12. Heads of household are defined as male regardless of occupation or position within the household (Article 206 of Civil Code Book 1). Male ownership of assets extended to children. Article 41 of the law on gender-based violence does try to redress polygamous or unlawful marriages with multiple wives by mandating equal distribution of property (without infringing on child rights of property).

13. See Garcia-Moreno, et al. (2005). In Rwanda, another DHS study also aggregates emotional, physical, and sexual violence; see Kishor and Johnson (2004). Panda and Agarwal (2005) separate out emotional violence but use an aggregate of physical and sexual violence in their analysis.

14. For a methodological discussion of the survey, see NISR/ORC (2006).

15. To avoid some of the cultural/interpretation difficulties in this type of research, it is preferred to measure violence by asking whether someone has experienced specifically defined acts as opposed to asking about violence in general. For the Conflict Tactics Scale, see Strauss (1990).

16. Heise (1998); Krahé, et al. (2005); WHO (2005).
17. As many families after the genocide took in relatives or close friends, the number of household members is included as well as the number of children.

18. Genocide intensity is a proxy for the level of gendered violence by using deaths during the genocide as a percentage of province population. A census conducted by the Government of National Unity was released in 2002 which provides estimates of deaths by province during the genocide; see Davenport and Stam (2001). There are a number of organizations which have provided estimates of deaths during the genocide. All, including the government census, are contentious; see Davenport and Stam (2001); Straus (2006). In this article, the government census is used as it is the only source that has records of deaths by province, interpreted here as an upper-bound estimate of deaths.

19. Garcia-Moreno, et al. (2005).

20. Heise and Garcia-Moreno (2002).

21. Garcia-Moreno, et al. (2005); Panda and Agarwal (2005).

22. González-Brenes (2004); McCloskey, et al. (2005).

23. Internal migration and changing demographics mean that one can only tentatively mention the association between areas with high-intensity killings during the genocide as also being areas with higher intimate partner violence reported 11 years later on. This might be an interesting line of future research to explore.

24. Meintjes, et al. (2002); Turshen and Twagiramariya (1998).

25. Neither would there appear to exist a logical explanation for why women who work for wages would report higher levels of sexual violence but not of other forms of violence.

\section{Aizer (2007).}

27. Kenya/Tanzania: Silberschmidt (2001). Rape across countries: Seifert (1996).

28. This does not include unemployed men. To distinguish between subsistence farmers (who comprise the majority of the workforce) and the unemployed (a very small proportion of the workforce), the analysis separated out the unemployed from those working without pay. 
29. Changing gender relations postwar is not a phenomenon unique to Rwanda. For instance, post-World War II, notably U.S. and U.K. middle- and upper-class women were expected to withdraw from the labor market back into unpaid household labor and reproductive activities, yet many wished to stay in the labor force.

\section{References}

Afeefa, A.R., B. Lee, K. Contini, et al. 2006. "GBV Programming in Rwanda: Actors, Activities, Collaboration, Coordination.” Final Report. Women's Legal Rights Initiative. Rwanda and Chemonics International.

Aizer, A. 2007. "Wages, Violence and Health in the Household." Cambridge, MA: National Bureau of Economic Research. Working Paper No. 13494.

Bloch, F. and V. Rao. 2002. "Terror as a Bargaining Instrument: A Case Study of Dowry Violence in Rural India.” American Economic Review. Vol. 92, No. 4, pp. 1029-1043.

Borer, T.A. 2009. "Gendered War and Gendered Peace: Truth Commissions and Postconflict Gender Violence: Lessons From South Africa." Violence Against Women. Vol. 15, No. 10, pp. 1169-1193.

Counts, D.A., J.Brown, and J. Campbell. 1992. Sanctions and Sanctuary: Cultural Perspectives on the Beating of Wives. Boulder, CO: Westview Press.

Davenport, C. and A Stam. 2001. "Understanding Rwandan Political Violence in 1994." www.genodynamics.com [accessed 9 May 2012].

Donovan, P. 2002. "Rape and HIV/AIDS in Rwanda." The Lancet. No. 360 (Supplement 1), s17-s18.

Filmer, D. and L.H. Pritchett. 1999. "The Effect of Household Wealth on Educational Attainment: Evidence from 35 Countries." Population and Development Review. Vol. 25, No. 1, pp. 85-120.

Filmer, D. and L.H. Pritchett. 2001. "Estimating Wealth Effects without Expenditure Data or Tears: An Application to Educational Enrollments in States of India." Demography. Vol. 38, No. 1, pp. 115-132.

Garcia-Moreno, C., H.A.F.M. Jansen, M. Ellsberg, et al. 2005. "WHO Multi-country Study on Women's Health and Domestic Violence Against Women." Geneva: World Health Organization.

González-Brenes, M. 2004. "Domestic Violence and Household Decisionmaking: Evidence from East Africa.” Working Paper. Department of Economics. Berkeley, CA: University of California, Berkeley.

Green, L.L. 2002. "Propaganda and Sexual Violence in the Rwandan Genocide: An Argument for Intersectionality in International Law." Columbia Human Rights Law Review. Vol. 33, pp. 733-776.

Heise, L. 1998. "Violence Against Women: An Integrated Ecological Framework." Violence Against Women. Vol. 4, No. 3, pp. 262-290.

Heise, L. and C. Garcia-Moreno. 2002. "Violence by Intimate Partners," in E.G.
Krug, et al., eds. World Report on Violence and Health. Geneva: World Health Organization.

Human Rights Watch. 1996a. "Shattered Lives: Sexual Violence During the Rwandan Genocide and its Aftermath." HRW Index No. 2084. http://www.hrw.org/reports/1996/Rwanda.htm\#P324_67660 [accessed 15 April 2012].

Human Rights Watch. 1996b. "Shattered Lives: Sexual Violence During the Rwandan Genocide and its Aftermath." Human Rights Watch. http://www.hrw.org/sites/default/files/reports/1996 Rwanda \%20Shattered\%2 0Lives.pdf [accessed 15 April 2012].

Human Rights Watch. 2004. "Struggling to Survive: Barriers to Justice for Rape Victims in Rwanda." Human Rights Watch. Vol. 16, No. 10(A). www.hrw.org/sites/default/files/reports/rwanda0904.pdf[accessed 15 April 2012].

Kishor, S. and K. Johnson. 2004. "Profiling Domestic Violence: A Multi-Country Study." Calverton, MD: ORC Macro.

Krahé, B., S. Bieneck, and I. Möller. 2005. "Understanding Gender and Intimate Partner Violence from an International Perspective.” Sex Roles. Vol. 52, Nos. 11 12 , p. 807.

Krug, E.G., L.L. Dahlberg, J.A. Mercy, et al. 2002. World Report on Violence and Health. Geneva: WHO. http://www.who.int/violence injury prevention/ violence/world_report/en/index.html [accessed 15 April 2012].

Martin, S.L., A.O. Tsui, K. Maitra, et al. 1999. "Domestic Violence in Northern India." American Journal of Epidemiology. Vol. 150, No. 4, pp. 417-426.

McCloskey, L.A., C. Williams, and U. Larsen. 2005. "Gender Inequality and Intimate Partner Violence Among Women in Moshi, Tanzania." International Family Planning Perspectives. Vol. 31, No. 3, pp. 124-130.

Meintjes, S., A. Pillay, and M. Turshen, eds. 2002. The Aftermath: Women in Post-Conflict Transformation. London, New York: Zed Books.

Ministry of Gender and Family Promotion. 2004. "Violence Against Women." Kigali: Republic of Rwanda.

[NISR/OCR] National Institute of Statistics Rwanda and ORC Macro. 2006. "Rwanda Demographic and Health Survey 2005." Calverton, MD: NISR and ORC Macro.

Panda, P. and B. Agarwal. 2005. "Marital Violence, Human Development and Women's Property Status in India.” World Development. Vol. 33, No. 5, pp. 823-850.

Pillay, A. 2002. "Violence Against Women in the Aftermath," pp. 35-45 in S. Meintjes, A. Pillay, and M. Turshen, eds. The Aftermath: Women in Post-Conflict Transformation. London, New York: Zed Books.

Powley, E. 2004. "Strengthening Governance: The Role of Women in Rwanda's Transition. A Summary." Paper presented at the United Nations Office of the Special Adviser on Gender Issues and Advancement of Women (OSAGI). Expert Group Meeting on “Enhancing Women's Participation in Electoral Processes in 
(C) www.epsjournal.org.uk - Vol. 7, No. 2 (2012)

Post-Conflict Countries." http://www.un.org/womenwatch/osagi/ meetings/2004/EGMelectoral/EP5-Powley.PDF [accessed 15 April 2012].

Seifert, R. 1996. "The Second Front: The Logic of Sexual Violence in Wars." Women's Studies International Forum. Vol. 19, Nos. 1-2, pp. 35-43.

Sideris, T. 2002. "Rape in War and Peace: Social Context, Gender, Power and Identity," pp. 142-158 in S. Meintjes, A. Pillay, and M. Turshen, eds. The Aftermath: Women in Post-Conflict Transformation. London, New York: Zed Books.

Silberschmidt, M. 2001. "Disempowerment of Men in Rural and Urban East Africa: Implications for Male Identity and Sexual Behavior." World Development. Vol. 29, No. 4, pp. 657-671.

Straus, S. 2006. The Order of Genocide: Race, Power, and War in Rwanda. Ithaca, NY: Cornell University Press.

Strauss, M.A. 1990. "Measuring Intrafamily Conflict and Violence: The Conflict Tactics (CT) Scales," pp. 39-47 in M.A. Strauss and R.J. Gelles, eds. Physical Violence in American Families: Risk Factors and Adaptations to Violence in 8,145 Families. New Brunswick, NJ: Transaction Publishers.

Turshen, M. and C. Twagiramariya. 1998. What Women Do in Wartime: Gender and Conflict in Africa. London, New York: Zed Books.

UNIFEM. 2008. "Rwandan Women Secure 56\% of Parliamentary Seats in Historic Election Result.” UNIFEM Press Release. Kigali: UNIFEM.

[WHO] World Health Organization. 2005. "WHO Multi-country Study on Women's Health and Domestic Violence against Women." Geneva: World Health Organization. 